\title{
Red Cell Fatty Acid Profile
}

National Cancer Institute

\section{Source}

National Cancer Institute. Red Cell Fatty Acid Profile. NCI Thesaurus. Code C129895.

The identification and quantitation of all of the fatty acids expressed in the red blood cells isolated from a subject. 